\title{
Pengaruh Perilaku Keluarga terhadap Penggunaan Jamban
}

\author{
Erlinawati Pane*
}

\begin{abstract}
Abstrak
Secara nasional, hanya 39\% rumah tangga yang menggunakan jamban yang sehat, di daerah perkotaan (60\%) lebih tinggi daripada di perdesaan (23\%). Penggunaan jamban merupakan salah satu masalah kesehatan yang penting di daerah perdesaan seperti Desa Sukamurni di Kabupaten Bekasi. Hanya 19,8\% rumah tangga yang mempunyai jamban sendiri di Desa Sukamurni. Tujuan penelitian ini adalah mengetahui determinan perilaku keluarga terhadap penggunaan jamban di Desa Sukamurni. Penelitian ini menggunakan desain cross-sectional. Sampel adalah ibu rumah tangga yang mempunyai anak balita sebanyak 196 responden yang dilaksanakan pada bulan April hingga Mei 2008. Pengumpulan data dilakukan dengan wawancara langsung menggunakan kuesioner. Hasil penelitian menunjukkan bahwa hanya 46,4\% keluarga yang menggunakan jamban, sedangkan yang tidak menggunakan jamban (53,6 \%) umumnya menggunakan sungai $(55,2 \%)$ dan empang $(38,1 \%)$ sebagai sarana buang air besar. Semua variabel yang diteliti berhubungan bermakna, meliputi pendidikan, pengetahuan, sikap, kepemilikan jamban, sarana air bersih, pembinaan petugas puskesmas dan dukungan aparat desa, kader Posyandu \& LSM terhadap penggunaan jamban. Pendidikan dan pengetahuan merupakan variabel konfounder, dan kepemilikan jamban merupakan faktor dominan sebagai determinan perilaku keluarga terhadap penggunaan jamban dengan nilai $\mathrm{OR}=27,03(5,224-139,912)$.
\end{abstract}

Kata kunci : Perilaku keluarga, penggunaan jamban

\begin{abstract}
National figure showed that only $39 \%$ household are using healthy latrine, in which $60 \%$ was in the city, much higher than $23 \%$ in rural area. Low latrine utilization is one of important health problem in rural area such as in Sukamurni Village, Bekasi District. There is only $19.8 \%$ of household have own latrine in Sukamurni Village. The purpose of the study is to explore the family behavior determinant on latrine utilization at Sukamurni Village, using cross sectional design. The sample is women who have child or children under five. Sample is then comprises of 196 respondents. Data are collected from April to May 2008 , using direct interview with a structured questionnaire. Result showed that only $46.4 \%$ households are occupying latrine, and the rest are using river (55.2\%) and pond (38.1\%) to defecate. As bivariate analysis of Chi Square test showed that all variables are statistically have significant relationship with family's behavior on latrine utilization. Those variables are: education, knowledge, attitude, latrine ownership, availability on clean water, IEC from health provider, and support from village leader, posyandu cadres, and related NGO. Advance analysis with Logistic Multiple Regression found that variables of education and knowledge are confounder. Meanwhile, latrine ownership is the dominant factor of family behavior determinant on latrine utilization, with $\mathrm{OR}=27.036$.
\end{abstract}

Key words : Family behavior, latrine utilization

*Seksi Pengendalian Mutu Balai Pelatihan Kesehatan Lemahabang, Jl. Raya Lemahabang No.1 Cikarang Utara, Bekasi 17550 (e-mail: erlinawatipane@yahoo.com) 
Pembangunan nasional berwawasan kesehatan, mendorong kemandirian masyarakat untuk hidup bersih dan sehat. Pemerintah berkewajiban memelihara dan meningkatkan pelayanan kesehatan yang bermutu, merata dan terjangkau, memelihara dan meningkatkan kesehatan individu, keluarga, masyarakat dan lingkungannya. Program lingkungan sehat terkait dengan komitmen global dalam mewujudkan Millenium Development Goals (MDG's). Salah satu tujuan MDGs yaitu "ensure environmental sustainability" atau menjamin berlanjutnya pembangunan lingkungan. Tujuan ini menargetkan pada tahun 2015 akan mengurangi separuh proporsi penduduk yang tidak memiliki akses terhadap air minum dan sanitasi dasar yang sehat. ${ }^{1}$

Keberhasilan pembangunan kesehatan dapat dilihat dari meningkatnya derajat kesehatan masyarakat, diantaranya melalui indikator Angka Kematian Bayi dan Angka Kematian Balita. Hasil Survei Demografi dan Kesehatan Indonesia (SDKI) 2002-2003, menyebutkan bahwa angka kematian bayi dan balita di Indonesia masih cukup tinggi yaitu 35 dan 46 per 1.000 kelahiran hidup. Bila dibandingkan dengan Provinsi Jawa Barat, angka kematian bayi dan balita lebih tinggi daripada angka nasional, yaitu 44 dan 50 per 1.000 kelahiran hidup. Penyebab tingginya angka kematian tersebut adalah karena penyakit-penyakit infeksi seperti diare, Infeksi Penyakit Saluran Pernafasan Akut (ISPA), tuberculosis (TBC) dan malaria. Penyakit diare menempati urutan pertama penyebab kematian pada bayi. Hasil SDKI 1997 menyebutkan bahwa prevalensi diare pada anak usia balita di Jawa Barat sebesar 12,7\%. Angka tersebut lebih tinggi bila dibandingkan dengan rata-rata nasional yaitu $10,4 \% .^{2}$

Penyediaan air bersih dapat mencegah penyakit diare sebesar 35\% dan penggunaan jamban sehat dapat mencegah penyakit diare sebesar $28 \%$. Angka kesakitan dan kematian karena diare, cenderung meningkat dengan penurunan penggunaan jamban. Ketika penggunaan kakus mencapai puncaknya di Daerah Istimewa Yogyakarta (DIY), angka kesakitan dan kematian diare terlihat paling rendah yaitu 100 dan 17 kasus per 100.000 penduduk. Sebaliknya, ketika tingkat penggunaan kakus berada pada level yang paling rendah di Kalimantan Barat, terlihat angka kesakitan dan kematian diare yang paling tinggi yakni 940 dan 166 per 100.000 penduduk.

Kepemilikan dan penggunaan jamban sehat merupakan salah satu indikator program Perilaku Hidup Bersih dan Sehat (PHBS) ditatanan rumah tangga. Berdasarkan hasil kajian PHBS, ${ }^{3}$ secara nasional persentase rumah tangga yang menggunakan jamban sehat sebesar $(39 \%)$, di perkotaan $(60 \%)$ jauh lebih tinggi dibanding pedesaan $(23 \%)$. Persentase rumah tangga yang menggunakan jamban sehat di Provinsi Jawa Barat sedikit di atas rata-rata nasional yaitu $39,6 \%$. Sedangkan, target yang diharapkan pada akhir tahun 2009 adalah 80\% keluarga memiliki akses terhadap jamban. ${ }^{4}$

Hasil pengkajian PHBS di Kabupaten Bekasi tahun 2003, menyebutkan bahwa keluarga yang belum memiliki akses jamban sebanyak 36,4\%. ${ }^{5}$ Desa Sukamurni adalah salah satu desa yang berada di Kecamatan Sukakarya dan merupakan Desa Sehat Percontohan di Kabupaten Bekasi. Pada tahun 2003, diketahui bahwa salah satu prioritas masalah kesehatan adalah banyak keluarga yang belum memiliki jamban keluarga $(92,4 \%)$. Terlihat ada peningkatan cakupan kepemilikan jamban di desa Sukamurni, tahun $2003(6,6 \%)$ dan tahun 2006 $(19,8 \%)$. Namun, peningkatan kepemilikan jamban masih sangat jauh dari target yang ditetapkan oleh Departemen Kesehatan RI (80\%). Selain itu, belum ada data pendukung yang menjelaskan perilaku keluarga termasuk anak balita terhadap penggunaan jamban di Desa Sukamurni.

Penelitian ini bertujuan untuk mengetahui determinan perilaku keluarga terhadap penggunaan jamban di Desa Sukamurni serta faktor-faktor yang berhubungan dengan perilaku keluarga terhadap penggunaan jamban tersebut. Faktor-faktor yang diteliti meliputi faktor predisposisi (pendidikan ibu, pengetahuan ibu tentang jamban, dan sikap ibu terhadap jamban), faktor pemungkin (kepemilikan jamban, dan ketersediaan sarana air bersih), dan faktor penguat (pembinaan oleh petugas Pusat Kesehatan Masyarakat /Puskesmas), dan dukungan aparat desa, kader Pos Pelayanan Terpadu (Posyandu) dan Lembaga Swadaya Masyarakat (LSM).

\section{Metode}

Penelitian ini menggunakan disain studi potong lintang (cross sectional) untuk mengetahui faktor predisposisi, faktor pemungkin, dan faktor penguat yang berhubungan dengan perilaku penggunaan jamban keluarga. Penelitian ini dilaksanakan di Desa Sukamurni Kecamatan Sukakarya, Kabupaten Bekasi pada Bulan April - Mei 2008. Populasi pada penelitian ini adalah semua rumah tangga yang tinggal menetap atau mempunyai kecenderungan untuk tinggal menetap di Desa Sukamurni, Kecamatan Sukakarya Kabupaten Bekasi. Sampel adalah ibu rumah tangga yang memiliki anak balita usia 12-59 bulan. Pemilihan subjek ibu rumah tangga karena dianggap lebih mengetahui perilaku dan kebiasaan anggota keluarga termasuk anak balita dalam penggunaan jamban sebagai sarana buang air besar. Besar sampel dalam penelitian ini dihitung berdasarkan rumus uji hipotesis beda 2 proporsi. ${ }^{6}$ Berdasarkan rumus tersebut, maka jumlah sampel yang diperlukan sebanyak 196 sampel. 
Tabel 1. Analisis Bivariat

\begin{tabular}{lll}
\hline Variabel & Katagori & P-value \\
\hline $\begin{array}{l}\text { Faktor Predisposisi } \\
\text { Pendidikan }\end{array}$ & $\begin{array}{l}\text { Tinggi } \\
\text { Rendah } \\
\text { Tinggi } \\
\text { Pengetahuan }\end{array}$ & 0,000 \\
Sikap & $\begin{array}{l}\text { Positif } \\
\text { Negatif }\end{array}$ & 0,000 \\
Faktor Pemungkin & Memiliki & 0,000 \\
Kepemilikan jamban & $\begin{array}{l}\text { Tidak memiliki } \\
\text { Ada }\end{array}$ & 0,000 \\
Sarana air bersih & Tidak ada & 0,000 \\
Faktor Penguat & Ada & \\
Pembinaan petugas & $\begin{array}{l}\text { Tidak ada } \\
\text { Ada } \\
\text { Tidak ada }\end{array}$ & 0,000 \\
Dukungan aparat & & 0,008 \\
\end{tabular}

Tabel 2. Hasil Analisis Multivariat

\begin{tabular}{llll}
\hline Variabel & OR & \multicolumn{1}{c}{$\mathbf{9 5} \% \mathbf{C I}$} & P value \\
\hline Pendidikan ibu & 17,383 & $0,188-1610,137$ & 0,217 \\
Pengetahuan ibu & 1,690 & $0,505-5,614$ & 0,392 \\
Sikap ibu & 8,457 & $3,180-22,487$ & 0,000 \\
Kepemilikan jamban & 27,036 & $5,224-139,912$ & 0,000 \\
Sarana air bersih & 7,539 & $2,365-24,037$ & 0,001 \\
Pembinaan petugas & 4,480 & $1,408-14,254$ & 0,011 \\
Dukungan aparat & 2,783 & $1,154-6,714$ & 0,023 \\
& & & \\
\hline
\end{tabular}

Data dikumpulkan melalui wawancara terstruktur menggunakan kuesioner secara tatap muka, dan observasi terhadap kepemilikan jamban dan ketersediaan sarana air bersih. Kuesioner sebelumnya telah diuji coba oleh peneliti pada 30 rumah tangga di daerah yang berbeda, untuk mendapatkan gambaran dari jawaban kuesioner yang diisi guna penyempurnaan kuesioner. Desa yang dipilih sebagai lokasi uji coba kuesioner adalah salah satu desa yang berada di wilayah Kecamatan Sukakarya yaitu Desa Sukaindah, dimana daerahnya memiliki karakteristik yang hampir sama dengan Desa Sukamurni. Dalam pengumpulan data peneliti dibantu oleh 5 (lima) orang tenaga pewawancara yaitu pegawai Bapelkes Lemahabang yang memiliki latar belakang pendidikan kesehatan dan telah dilatih sebelumnya. Setelah data terkumpul, dilakukan analisis data secara bertahap mulai dari analisis univariat, bivariat, serta multivariat dengan menggunakan program komputer.

\section{Hasil}

Analisis Univariat

Sekitar $46,4 \%$ responden yang menyatakan keluar- ganya menggunakan jamban dan $53,6 \%$ yang menyatakan keluarganya tidak menggunakan jamban sebagai sarana buang air besar (BAB). Keluarga yang tidak menggunakan jamban sebagian besar menggunakan sungai/kali $(55,2 \%)$, empang $(38,1 \%)$, selokan $(3,8 \%)$ dan kebun/sawah $(2,9 \%)$ sebagai tempat untuk BAB. Faktor predisposisi dalam penelitian ini terdiri dari tiga variabel meliputi pendidikan ibu, pengetahuan ibu dan sikap ibu terhadap jamban. Gambaran faktor pemungkin dalam penelitian ini terdiri dari dua variabel yaitu kepemilikan jamban dan ketersediaan sarana air bersih. Kepemilikan jamban dibagi menjadi dua yaitu memiliki (jamban sendiri) sebanyak 44 responden $(22,4 \%)$ dan tidak memiliki (jamban bersama, umum atau tidak ada) sebanyak 152 responden $(77,6 \%)$. Ketersediaan sarana air bersih dibagi dua yaitu ada sebanyak 149 responden $(76,0 \%)$ dan tidak ada sebanyak 47 responden $(24,0 \%)$.

Faktor penguat terdiri dari dua variabel pembinaan penggunaan jamban oleh petugas puskesmas dan dukungan aparat desa, kader posyandu dan LSM. Pembinaan penggunaan jamban oleh petugas puskesmas $(19,9 \%)$, ada dukungan aparat desa, kader posyandu dan $\operatorname{LSM}(53,1 \%)$.

\section{Analisis Bivariat}

Berdasarkan hasil analisis bivariat diketahui semua variabel independen yang diteliti berhubungan dengan perilaku keluarga terhadap penggunaan jamban. Masing-masing variabel tersebut dapat dijelaskan pada Tabel 1.

\section{Analisis Multivariat}

Hasil analisis multivariat terdapat lima variabel yang berhubungan dengan perilaku keluarga terhadap penggunaan jamban, yaitu sikap ibu terhadap jamban, kepemilikan jamban, ketersediaan sarana air bersih, pembinaan penggunaan jamban oleh petugas puskesmas, dan dukungan aparat desa, kader posyandu dan LSM. Dari kelima variabel tersebut, yang merupakan faktor dominan berhubungan dengan perilaku keluarga terhadap penggunaan jamban adalah variabel kepemilikan jamban dengan $\mathrm{OR}=27$, artinya keluarga yang memiliki jamban akan mempunyai peluang 27 kali untuk menggunakan jamban dibandingkan dengan keluarga yang tidak memiliki jamban. Sedangkan, pendidikan ibu dan pengetahuan ibu tentang jamban merupakan variabel confounder (perancu).

Pada analisis multivariat terlihat bahwa pendidikan dan pengetahuan ibu tidak berhubungan bermakna dengan perilaku keluarga menggunakan jamban (nilai $\mathrm{p}$ 0,217 dan 0,292). Variabel yang berhubungan bermakna dengan perilaku keluarga menggunakan jamban adalah sikap ibu (nilai $\mathrm{p}=0,000 ; \mathrm{OR}=8,5 ; 95 \% \mathrm{CI}$ OR $=$ 
3,18-22,49); kepemilikan jamban (nilai $\mathrm{p}=0,000$; OR $=27,04 ; 95 \%$ CI OR = 5,24 -139, 91); sarana air bersih (nilai $\mathrm{p}=0,001$; $\mathrm{OR}=7,54 ; 95 \% \mathrm{CI} O \mathrm{OR}=2,36$ 24,04 ); pembinaan petugas (nilai $\mathrm{p}=0,011$; $\mathrm{OR}=$ 4,48; $95 \%$ CI OR = 1,41-14,25); dukungan aparat (nilai $\mathrm{p}=0,023 ; \mathrm{OR}=2,7 ; \quad 95 \%$ CI OR $=1,15-6,71$ ) (Lihat Tabel 2).

\section{Pembahasan}

Penelitian ini menggunakan desain potong lintang (cross sectional), sehingga hasil yang diperoleh tidak dapat memberikan penjelasan hubungan sebab akibat. Akan tetapi, hanya menunjukkan hubungan antara variabel independen dan dependen yang dikaji secara bersamaan.

Hasil penelitian menunjukkan proporsi penggunaan jamban $(46,4 \%)$ di Desa Sukamurni ini sedikit lebih tinggi bila dibandingkan dengan penelitian yang dilakukan oleh Kasnodihardjo, ${ }^{7}$ dimana hanya $33,5 \%$ penduduk di Kabupaten Subang yang membuang kotoran manusia di jamban. Kondisi ini dapat dijelaskan bahwa pada tahun 2005 Desa Sukamurni telah dicanangkan sebagai Desa Sehat Percontohan di Kabupaten Bekasi, sehingga lebih tingginya proporsi penggunaan jamban tersebut dibanding dengan rata-rata nasional (39\%) maupun Provinsi Jawa Barat $(39,6 \%)$ kemungkinan karena adanya dukungan dari aparat desa, kader posyandu dan Lembaga Swadaya Masyarakat (LSM) atau petugas puskesmas berupa ajakan, himbauan ataupun pemberian informasi tentang kesehatan lingkungan agar masyarakat mau berperilaku hidup bersih dan sehat, diantaranya adalah dengan menggunakan jamban sebagai sarana buang air besar keluarga baik milik sendiri, bersama maupun jamban umum.

Hasil penelitian diketahui bahwa keluarga yang tidak menggunakan jamban sebagian besar menggunakan kali/sungai $(55,2 \%)$ dan empang $(38,1 \%)$ sebagai sarana buang air besar keluarga. Hal ini dapat menjadi salah satu penyebab pencemaran air sungai dan tanah yang berada di Desa Sukamurni. Hasil wawancara peneliti dengan beberapa responden, diketahui bahwa alasan mereka tidak menggunakan jamban sebagai sarana buang air besar adalah karena keluarga tidak memiliki jamban sendiri. Selain itu, lokasi jamban umum yang relatif jauh letaknya dari tempat tinggal mereka dibandingkan dengan sungai atau empang yang ada.

Pendidikan merupakan kebutuhan dasar manusia yang sangat penting untuk mengembangkan diri, karena dengan pendidikan yang tinggi seseorang dapat memiliki pengetahuan yang lebih baik. Hasil penelitian ini membuktikan bahwa pendidikan ibu mempunyai hubungan yang erat dengan perilaku keluarga terhadap penggunaan jamban, dimana ibu dengan pendidikan tinggi mempu- nyai peluang untuk menggunakan jamban 17,4 kali dibandingkan dengan ibu dengan pendidikan rendah. Hal ini menunjukkan bahwa semakin tinggi pendidikan ibu maka semakin luas pula pengetahuan dan wawasannya, sehingga peranan pendidikan ibu sangat mempengaruhi perilaku keluarga terhadap penggunaan jamban sebagai sarana buang air besar. Hal ini mendukung penelitian yang dilakukan oleh Suherman, ${ }^{8}$ yang mengatakan bahwa ada hubungan antara pendidikan dengan ketidakmauan menggunakan jamban pada keluarga, dimana responden yang berpendidikan rendah mempunyai risiko untuk tidak mau menggunakan jamban pada waktu Buang Air Besar (BAB) dibandingkan yang berpendidikan tinggi.

Berdasarkan hasil analisis lebih lanjut, diketahui bahwa pendidikan ibu merupakan variabel confounder terhadap hubungan kepemilikan jamban dengan perilaku keluarga terhadap penggunaan jamban. Kondisi ini dapat dijelaskan bahwa peranan pendidikan ibu sangat besar terhadap kepemilikan jamban dalam sebuah keluarga. Hasil penelitian ini membuktikan bahwa sebagian besar ibu berpendidikan tinggi $(80,0 \%)$ memiliki jamban keluarga sendiri. Hal ini juga dapat menjelaskan bahwa seorang ibu dalam rumah tangga mempunyai peranan yang besar dalam mengurus rumah tangga, mengasuh, mendidik, melindungi anak-anaknya dan menjaga kesehatan keluarganya.

Pengetahuan ibu tentang jamban mempunyai hubungan bermakna dengan perilaku keluarga terhadap penggunaan jamban. Berdasarkan hasil uji keeratan hubungan diketahui ibu yang dengan pengetahuan tinggi tentang jamban mempunyai peluang untuk menggunakan jamban 1,7 kali dibandingkan ibu dengan pengetahuan rendah tentang jamban. Temuan ini sejalan dengan penelitian Widaryoto, ${ }^{9}$ menyatakan bahwa ada hubungan antara pengetahuan kepala keluarga tentang jamban dengan praktik penggunaan jamban di Kecamatan Kepahiang, dimana responden dengan pengetahuan baik mempunyai peluang 56,9 kali menggunakan jamban dibanding dengan responden dengan pengetahuan kurang baik.

Berdasarkan hasil analisis lebih lanjut diketahui bahwa variabel pengetahuan ibu tentang jamban merupakan variabel confounder terhadap hubungan pendidikan ibu dengan perilaku keluarga terhadap penggunaan jamban. Kondisi ini dapat dijelaskan bahwa ibu yang mempunyai pengetahuan tinggi tentang jamban pada umumnya adalah ibu berpendidikan tinggi. Hal ini kemungkinan disebabkan karena ibu yang berpendidikan tinggi lebih mudah memahami (comprehension) dan mampu menginterpretasikan secara benar objek yang diketahui yang diikuti dengan proses aplikasi (application) dalam kehidupan sehari-hari. Jadi, semakin tinggi pendidikan ibu maka semakin tinggi pula pengetahuannya 
yang dapat mempengaruhi perilaku keluarga terhadap penggunaan jamban. Hal ini terbukti bahwa 93,3\% ibu berpendidikan tinggi memiliki pengetahuan tinggi tentang jamban.

Sebaliknya ibu berpendidikan rendah ternyata banyak yang memiliki pengetahuan tinggi tentang jamban $(77,9 \%)$ tetapi pengetahuan yang dimiliki tidak diaplikasikan dalam hal penggunaan jamban. Hal ini kemungkinan disebabkan pengetahuan ibu yang berpendidikan rendah tentang jamban termasuk tinggi tetapi pengetahuan tersebut hanya sekedar tahu (know) saja tanpa ada penjelasan secara rinci tentang manfaat dan kegunaan dari penggunaan jamban sehat bagi keluarganya. Rendahnya kepemilikan jamban di Desa Sukamurni dapat menjadi penyebab keluarga tidak menggunakan jamban walaupun memiliki pengetahuan yang tinggi tentang jamban. Selain itu, kurangnya pemahaman ibu tentang jamban sehat kemungkinan karena sebagian besar ibu $(80,1 \%)$ tidak mendapat pembinaan penggunaan jamban oleh petugas puskesmas.

Sikap ibu terhadap jamban merupakan faktor predisposisi dari perilaku keluarga terhadap penggunaan jamban. Hasil penelitian menunjukkan adanya hubungan yang bermakna antara sikap ibu terhadap jamban dengan perilaku keluarga terhadap penggunaan jamban (OR $=8,5$ ) artinya, ibu yang bersikap positif terhadap jamban mempunyai peluang untuk menggunakan jamban $8,5 \mathrm{ka}-$ li dibanding ibu yang bersikap negatif terhadap jamban. Temuan ini sejalan dengan penelitian Suherman yang menyebutkan sikap Kepala Keluarga (KK) terhadap jamban mempunyai hubungan dengan ketidakmauan keluarga menggunakan jamban, dimana KK yang memiliki sikap positif lebih banyak mau menggunakan jamban $(57,85 \%)$ dibandingkan yang tidak menggunakan $(37,98 \%)$. Begitu pula dengan penelitian Zaahara, ${ }^{10}$ menyebutkan bahwa adanya hubungan positif antara sikap ibu terhadap kebersihan lingkungan dengan perilaku hidup sehat ibu dalam keluarga. Semakin positif sikap ibu terhadap kebersihan lingkungan, maka semakin tinggi kualitas perilaku hidup sehat ibu dalam keluarga.

Kepemilikan jamban di Desa Sukamurni ternyata sangat rendah $(22,4 \%)$ jika dibandingkan dengan kepemilikan jamban di Kabupaten Bekasi $(56,02 \%)$ maupun Provinsi Jawa Barat $(60,5 \%)$. Hasil analisis selanjutnya diketahui bahwa kepemilikan jamban sangat erat kaitannya dengan perilaku keluarga terhadap penggunaan jamban $(\mathrm{OR}=27,04)$, artinya keluarga yang memiliki jamban berpeluang 27 kali untuk menggunakan jamban sebagai tempat buang air besar dibandingkan dengan keluarga yang tidak memiliki jamban.

Penelitian ini menemukan bahwa sebanyak 32,2\% keluarga yang tidak memiliki jamban sendiri mau meng- gunakan jamban bersama atau jamban umum yang ada di desa sebagai sarana buang air besar. Artinya, masih adanya kemauan dari keluarga yang tidak memiliki jamban sendiri untuk menggunakan jamban sebagai fasilitas buang air besar. Hal ini tidak sesuai dengan penelitian Suherman, 8 di Kecamatan Walantaka Kabupaten Serang, dimana sebanyak 51,6\% keluarga tidak mau menggunakan jamban walaupun telah memiliki jamban sendiri.

Temuan ini membuktikan pula bahwa kepemilikan jamban sebagai faktor pemungkin (enabling) perilaku kesehatan, ternyata merupakan determinan yang paling dominan dalam hal penggunaan jamban di Desa Sukamurni. Tersedianya jamban sebagai salah satu fasilitas kesehatan keluarga memungkinkan anggota keluarga untuk menggunakan jamban sebagai sarana buang air besar.

Berdasarkan hasil wawancara peneliti dengan aparat desa dan beberapa kader posyandu, diketahui bahwa alasan sebagian besar warga desa tidak mau membuat jamban karena pembuatan jamban yang memenuhi syarat kesehatan (jamban leher angsa dengan septik tank) dianggap mahal, sehingga warga memilih buang air besar di sungai atau empang karena tidak memerlukan biaya. Masyarakat enggan untuk membuat jamban sederhana seperti jamban cemplung/cubluk. Alasannya karena kondisi wilayah Desa Sukamurni yang dilintasi aliran sungai serta rawan banjir, sehingga jika sungai meluap dan banjir terjadi maka tinja pada tempat penampungan kakus cubluk akan meluap bersama banjir. Hal tersebut menyebabkan masyarakat desa tidak mau membuat kakus cubluk walaupun lebih murah biayanya dibandingkan jamban leher angsa dengan septik tank.

Selain kepemilikan jamban, ketersediaan sarana air bersih di rumah tangga merupakan faktor pemungkin untuk berperilaku sehat, karena dengan tersedianya sarana air bersih akan lebih memudahkan anggota keluarga untuk menjaga kebersihan diri setelah buang air besar dan jamban yang digunakan. Hasil penelitian ini menunjukkan hubungan yang bermakna antara ketersediaan sarana air bersih dengan perilaku keluarga terhadap penggunaan jamban $(\mathrm{OR}=7,5)$. Artinya, keluarga yang ada sarana air bersih di rumahnya mempunyai peluang untuk menggunakan jamban 7,5 kali dibandingkan dengan keluarga yang tidak ada sarana air bersih. Temuan ini sejalan dengan penelitian Widaryoto, ${ }^{9}$ menyatakan bahwa jamban yang tersedia air di dalamnya lebih banyak digunakan yakni sebesar 98,4\% dibandingkan jamban yang tidak tersedia air yakni sebesar $50,7 \%$.

Salah satu kegiatan pokok puskesmas adalah kesehatan lingkungan dan penyuluhan kesehatan masyarakat, dimana pelaksanaan kegiatan pokok tersebut diarahkan 
kepada keluarga sebagai satuan masyarakat terkecil. Penelitian ini menunjukkan adanya hubungan bermakna antara pembinaan penggunaan jamban oleh petugas puskesmas dengan perilaku keluarga terhadap penggunaan jamban $(\mathrm{OR}=4,5)$. Artinya, keluarga yang mendapat pembinaan penggunaan jamban oleh petugas puskesmas mempunyai peluang untuk menggunakan jamban 4,5 kali dibandingkan dengan keluarga yang tidak mendapat pembinaan.

Pembinaan yang dilakukan oleh puskesmas ada 2 jenis, yaitu melalui penyuluhan dan atau kunjungan ke rumah penduduk. Jika dilihat dari cakupan pembinaan yang dilakukan oleh petugas puskesmas $(19,9 \%)$ pada penelitian ini, ternyata sebagian besar menerima pembinaan petugas puskesmas adalah dengan cara penyuluhan/pemberian informasi $(84,2 \%)$ saja, sedangkan sisanya $7,9 \%$ hanya melalui kunjungan rumah dan $7,9 \%$ melalui menerima kedua jenis pembinaan tersebut.

Dalam pembangunan kesehatan di wilayah pedesaan, adanya dukungan dari aparat desa (kepala desa dan perangkat desa) dianggap penting oleh masyarakat, sehingga segala tindakan serta ucapannya akan mendapat perhatian dan diikuti oleh warganya. Selain aparat desa, kader posyandu dan LSM yang bergerak dibidang kesehatan dapat pula memberikan dukungan terhadap warga desa dalam pembangunan kesehatan. Hasil penelitian menunjukkan adanya hubungan yang bermakna antara dukungan aparat desa, kader posyandu dan LSM dengan perilaku keluarga terhadap penggunaan jamban. Hasil uji keeratan hubungan diketahui bahwa keluarga yang memperolah dukungan dari aparat desa, kader posyandu dan LSM mempunyai peluang untuk menggunakan jamban 2,8 kali dibandingkan dengan keluarga yang tidak mendapat dukungan.

Jenis dukungan dilihat dari dua aspek, yaitu dukungan berupa penyuluhan/pemberian informasi tentang jamban sehat dan atau dukungan berupa bantuan pembuatan jamban di lingkungan tempat tinggal responden. Bila dilihat dari persentase dukungan yang diperoleh responden $(53,1 \%)$, ternyata dukungan yang terbesar adalah berupa bantuan pembuatan jamban $(79,8 \%)$, diikuti dengan penyuluhan disertai bantuan pembuatan jamban $(15,4 \%)$ dan dukungan berupa penyuluhan $(4,8 \%)$. Pihak yang paling banyak memberikan dukungan dalam pembuatan jamban tersebut adalah dari aparat desa $(72,7 \%)$, LSM $(22,2 \%)$ dan lain-lain $(5,1 \%)$. Penelitian ini membuktikan bahwa besarnya dukungan dari aparat desa, kader posyandu dan LSM yang bergerak dibidang kesehatan, terbukti sebagai faktor penguat (reinforcing factor) yang menjadi pendorong masyarakat untuk menggunakan jamban, dimana 42 responden $(46,2 \%)$ dari 91 responden yang menyatakan keluarganya menggunakan jamban, ternyata memanfaatkan jamban umum yang ada di lingkungan tempat tinggalnya sebagai sarana buang air besar.

\section{Kesimpulan}

Perilaku penggunaan jamban sebagai sarana buang air besar di Desa Sukamurni Kecamatan Sukakarya Kabupaten Bekasi masih belum sehat karena sebagian besar keluarga tidak memiliki jamban dan terbiasa menggunakan sungai atau empang. Perilaku keluarga terhadap penggunaan jamban dipengaruhi oleh 3 (tiga) faktor utama yakni faktor predisposisi (pendidikan ibu, pengetahuan ibu tentang jamban, sikap ibu terhadap jamban), faktor pemungkin (kepemilikan jamban, ketersediaan sarana air bersih) dan faktor penguat (pembinaan oleh petugas puskesmas, dukungan aparat desa, kader posyandu dan LSM). Pendidikan ibu dan pengetahuan ibu tentang jamban merupakan variabel confounder (perancu). Faktor pemungkin (enabling factor) yakni kepemilikan jamban sebagai faktor dominan yang berhubungan dengan perilaku keluarga terhadap penggunaan jamban, dimana keluarga yang memiliki jamban akan mempunyai peluang 27,04 $(5,224$ - 139,912) kali untuk menggunakan jamban dibandingkan dengan keluarga yang tidak memiliki jamban.

\section{Daftar Pustaka}

1. Wikipedia. Tujuan pembangunan millenium. Wikipedia Indonesia; 2008 [edisi 2008, diakses tanggal 6 Maret 2008]. Diunduh dari: http://id.wikipedia.org/wiki/.

2. Badan Pusat Statistik. Survei kesehatan demografi Indonesia (SDKI) 1997. Jakarta: BPS; 1998.

3. Departemen Kesehatan Republik Indonesia. Perilaku hidup bersih dan sehat di Indonesia 2004. Jakarta: Pusat Promosi Kesehatan Depkes RI; 2006.

4. Departemen Kesehatan Republik Indonesia. Rencana strategis Departemen Kesehatan 2005-2009. Jakarta: Depkes RI; 2006.

5. Dinas Kesehatan Republik Indonesia. Master plan pembangunan kesehatan Kabupaten Bekasi tahun 2004-2007. Edisi Revisi. Pemerintah Daerah Kabupaten Bekasi; 2004.

6. Ariawan I. Besar dan metode sampel pada penelitian kesehatan. Depok: Fakultas Kesehatan Masyarakat Universitas Indonesia; 1998.

7. Kasnodihardjo. Gambaran perilaku penduduk mengenai kesehatan lingkungan di Daerah Pedesaan Subang Jawa Barat. Cermin Dunia Kedokteran. 1997; 119.

8. Suherman F. Faktor-faktor yang berhubungan dengan ketidakmauan menggunakan jamban keluarga pada lingkungan perumahan penduduk di Kecamatan Walantaka Kabupaten Serang [tesis]. Depok: Fakultas Kesehatan Masyarakat Universitas Indonesia; 2001.

9. Widaryoto.Faktor-faktor yang berhubungan dengan praktik penggunaan jamban pada kepala keluarga yang memiliki jamban di Kecamatan Kepahiang Kabupaten Rejang Lebong Provinsi Bengkulu 